九州大学学術情報リポジトリ

Kyushu University Institutional Repository

\title{
Denaturation of the Bacillus stearothermophilus Dihydrolipoamide Dehydrogenase in the Presence of Guanidine-HCl at Low Temperature
}

Hi romasa, Yasuaki

Laboratory of Protein Chemistry and Engineering, Department of Genetics Resources Technology, Graduate School of Bioresource and Bioenvironmental Sciences, Kyushu University

Meno, Kohj i

Laboratory of Protein Chemistry and Engineering, Department of Genetics Resources Technology, Graduate School of Bioresource and Bioenvironmental Sciences, Kyushu University

Aso, Yoichi

https://doi.org/10.5109/4509

出版情報: 九州大学大学院農学研究院紀要. 47 (2)，pp.387-394，2003-02-01. Faculty of Agriculture, Kyushu University

バージョン :

権利関係 : 


\title{
Denaturation of the Bacillus stearothermophilus Dihydrolipoamide Dehydrogenase in the Presence of Guanidine-HCl at Low Temperature
}

\author{
Yasuaki HIROMASA*, Kohji MENO* and Yoichi ASO ${ }^{\dagger}$ \\ Laboratory of Protein Chemistry and Engineering, Department of Genetic Resources \\ Technology, Faculty of Agriculture, Kyushu University, Fukuoka 812-8581 \\ (Received October 22, 2002 and accepted November 7, 2002)
}

\begin{abstract}
Denaturation of the Bacillus stearothermophilus dihydrolipoamide dehydrogenase induced by incubation with guanidine- $\mathrm{HCl}(\mathrm{GdnHCl})$ at $4{ }^{\circ} \mathrm{C}$ was examined. Enzyme activity was amplified by 2.5 times in $0.2 \mathrm{M} \mathrm{GdnHCl}$; such an increase in activity was also detected in $\mathrm{NaCl}$ and $\mathrm{KCl}$ at concentrations less than $1 \mathrm{M}$, but not in urea. With increasing amount of $\mathrm{GdnHCl}$, the enzyme lost half and all of its activity in $1.0 \mathrm{M}$ and $1.6 \mathrm{M} \mathrm{GdnHCl}$, respectively. Notable changes in fluorescence spectra of Trp residue and FAD cofactor besides circular dichroism in far UV region were detected and insufficiently correlated to the inactivation. Based on changes in fluorescence intensities and molecular ellipticity, a two-state transition equilibrium was suggested; transition midpoints were roughly at $1.7 \mathrm{M} \mathrm{GdnHCl}$. In $\mathrm{GdnHCl}$ at concentrations above $2 \mathrm{M}$, the enzyme released $\mathrm{FAD}$ and formed inactive aggregate. Effects by $\mathrm{GdnHCl}$ at concentrations less than $1.4 \mathrm{M}$ were mostly cancelled by its removal. Most results were similar to those from studies on the enzyme being one of components of pyruvate dehydrogenase complex.
\end{abstract}

\section{INTRODUCTION}

The Bacillus stearothermophilus dihydrolipoamide dehydrogenase [EC 1.8.1.4] (E3) is one of the three component enzymes of pyruvate dehydrogenase complex (PDC) facilitating the synthesis of an acetyl CoA and supplying the Krebs cycle with the cofactor; others are pyruvate decarboxylase [EC 1.2.4.1] (E1) and lipoate acetyltransferase [EC 2.3.1.12] (E2) (Mande et al., 1996; Perham, 1996; Perham, 2000). E1 and E2 co-catalyze the acetyl transfer from pyruvate to CoA, and the lipoyl group covalently attached to E2 is converted into corresponding dihydrolipoyl group. E3 is a dimeric flavoprotein catalyzing the re-oxidation of the dihydrolipoyl group using $\mathrm{FAD}$ and $\mathrm{NAD}^{+}$; different types of $\mathrm{E} 3$ have been also reported (de Kok and Berkel, 1996). We have been interested in the disintegration mechanism of a gigantic assembly of polypeptides and examined changes in PDC induced by various factors such as a chaotropic reagent (Hiromasa et al., 1997; Aso et $a l .$, 1998). Since a variety of intra- and inter-polypeptide interactions are expected to become intricate in PDC, especially upon its disintegration, better understanding of the mechanism requires both the knowledge of stabilities of components in PDC and isolated from PDC. Based on results from thermal inactivation studies, E3 is suggested stabilized in PDC and in E2-E3 complex (Hiromasa et al., 2000; Miyata et al., 2002; Aso et al.,

\footnotetext{
* Laboratory of Protein Chemistry and Engineering, Department of Genetic Resources Technology, Graduate School of Bioresource and Bioenvironmental Sciences, Kyushu University

+ Corresponding author (E-mail: yaso@agr.kyushu-u.ac.jp)
} 
2002). Although the stabilizing mechanism of E3 is still under investigation in our laboratory, we have had a question whether the stability of E3 to a denaturant also depends on its environment. We already examined the effects of guanidine hydrochloride (GdnHCl) on PDC and have known some changes of E3 in PDC: namely, the effects of incubation with $\mathrm{GdnHCl}$ for $24 \mathrm{~h}$ at $4^{\circ} \mathrm{C}$ and those of the successive removal of $\mathrm{GdnHCl}$ by dialysis for $48 \mathrm{~h}$ at $4^{\circ} \mathrm{C}$ (Meno et al., 2002). We however have poor knowledge of GdnHCl-induced changes of isolated E3, especially those induced under similar conditions. The present study deals with effects of $\mathrm{GdnHCl}$ on isolated $\mathrm{E} 3$ at $4{ }^{\circ} \mathrm{C}$.

\section{MATERIALS AND METHODS}

\section{Chemicals and enzyme}

All chemicals used were of the highest grade commercially available. FAD and $N$-acetyl tryptophanamide (NATA) were purchased from Sigma. Unless otherwise noted, the buffer used was $20 \mathrm{mM}$ sodium phosphate buffer ( $\mathrm{pH} 7$ ) containing $2 \mathrm{mM}$ EDTA and $0.15 \mathrm{mM}$ phenylmethanesulfonyl fluoride: standard buffer. The amount of GdnHCl was confirmed by measuring refractive index (Pace et al., 1989). The B. stearothermophilus E3 (diaphorase II) was purchased from Unitika and further purified by an ion-exchange chromatography on a HiTrap-Q column (2 ml) according to the method previously reported (Hiromasa et al., 2000).

\section{Protein, FAD, activity, and spectroscopic measurements}

Protein amount was measured with a BioRad protein assay kit; bovine serum albumin (BSA) was used as a standard protein. FAD amount was measured by the method previously reported (Hiromasa et al., 1997). After a standard buffer (1.2 ml) containing $0.132 \mathrm{mg}$ of $\mathrm{E} 3$ and various amount of $\mathrm{GdnHCl}$ was incubated at $4^{\circ} \mathrm{C}$ for $24 \mathrm{~h}$, an enzyme activity and fluorescence spectra were measured. The activity was measured at $30^{\circ} \mathrm{C}$ in the presence of same amount of $\mathrm{GdnHCl}$ as used upon incubation; dihydrolipoamide was used as a substrate and changes in absorbance at $340 \mathrm{~nm}$ were continuously monitored (Hiromasa et al., 1993; Hiromasa et al., 1995). The fluorescence spectra ascribed to Trp residue and $\mathrm{FAD}$ cofactor were measured at $25^{\circ} \mathrm{C}$ upon excitation at $295 \mathrm{~nm}$ and $366 \mathrm{~nm}$, respectively, with a Hitachi 650-60 fluorescence spectrophotometer. For the measurement of circular dichroism (CD) spectrum, a standard buffer $(1.0 \mathrm{ml})$ containing $0.074 \mathrm{mg}$ of $\mathrm{E} 3$ and various amount of $\mathrm{GdnHCl}$ was incubated at $4^{\circ} \mathrm{C}$ for $40 \mathrm{~h}$. CD spectrum was measured between 210 and $250 \mathrm{~nm}$ at $25^{\circ} \mathrm{C}$ with a Jasco J-720 spectropolarimeter and a 3-mm cell.

\section{Analyses by gel filtration and ultracentrifugation}

A standard buffer $(1.0 \mathrm{ml})$ containing $0.132 \mathrm{mg}$ of $\mathrm{E} 3$ and various amount of $\mathrm{GdnHCl}$ was incubated at $4^{\circ} \mathrm{C}$ for $24 \mathrm{~h}$ and filtered at $20^{\circ} \mathrm{C}$ through a Superose $12 \mathrm{HR}$ column with a Tosoh 8020 HPLC system. The column was developed at the flow rate of 0.5 or $1.0 \mathrm{ml} / \mathrm{min}$ with the standard buffer containing the same amount of $\mathrm{GdnHCl}$ as used upon incubation. Marker proteins (Sigma) used for gel filtration were BSA, RNase A, DNase I, $\beta$ amylase, and alcohol dehydrogenase; Blue dextran 2000 (Pharmacia) was also used to evaluate the void volume of the column. Analytical ultracentrifugation was done at $20^{\circ} \mathrm{C}$ 
by a Beckman XL-A ultracentrifuge with an An-60 Ti rotor and 12-mm double sector cell. Sedimentation equilibrium method at $10,000 \mathrm{rpm}$ was used, and acquired data were analyzed by a Beckman XLAEQ program (Beckman). Partial specific volume of E3 was calculated $0.743 \mathrm{ml} / \mathrm{g}$ based on its amino acid composition (Lebowitz et al., 2002). Solvent densities used for calculation were $0.9986 \mathrm{~g} / \mathrm{ml}$ and $1.0386 \mathrm{~g} / \mathrm{ml}$ for standard buffer and the buffer containing $2 \mathrm{M} \mathrm{GdnHCl}$, respectively.

\section{RESULTS}

Relatively low concentrations of $\mathrm{GdnHCl}$ raised an enzyme activity notably; the activity maximum was at $0.2 \mathrm{M} \mathrm{GdnHCl}$ and 2.5 times higher than that in the absence of GdnHCl (Fig. 1A). Larger amount of GdnHCl inhibited E3; the activity was halved in $1 \mathrm{M}$ $\mathrm{GdnHCl}$ and lost completely in $1.8 \mathrm{M} \mathrm{GdnHCl}$. Urea at concentrations less than $1.0 \mathrm{M}$ was ineffective. The effects of $\mathrm{NaCl}$ and $\mathrm{KCl}$ were similar to those of $\mathrm{GdnHCl}$, although the activity increased depending on salt concentration less sharply than on $\mathrm{GdnHCl}$ concentration (Fig. 1A).

CD spectrum was measured in far UV region. The molar ellipticity at $222 \mathrm{~nm}$ increased in the presence of $\mathrm{GdnHCl}$ at concentrations above $1.2 \mathrm{M}$ and reached a plateau in $2 \mathrm{M} \mathrm{GdnHCl}$, showing degenerated spectrum (Fig. 1B). With increasing amount of $\mathrm{GdnHCl}$, the fluorescence spectra ascribed to Trp residue and FAD cofactor also changed:
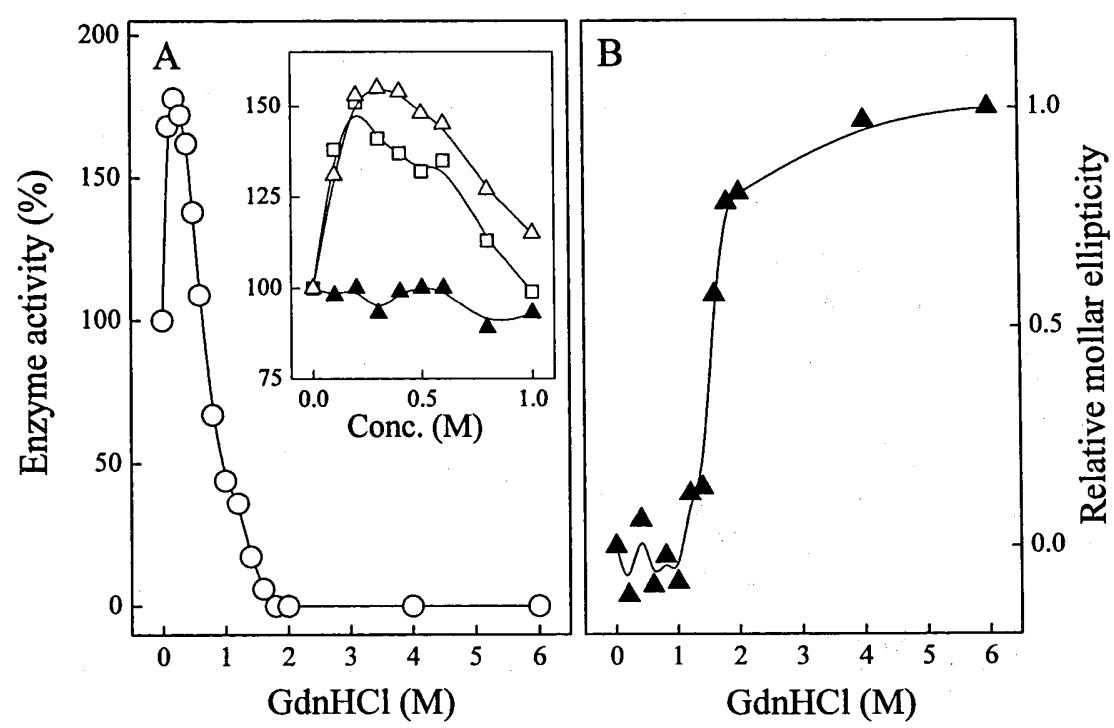

Fig. 1. Changes in enzyme activity and molecular ellipticity. Panel A. After incubation at $4{ }^{\circ} \mathrm{C}$ for $24 \mathrm{~h}$, the enzyme activity was measured in the presence of corresponding reagent: $\mathrm{GdnHCl}(\mathrm{O})$, urea $(\boldsymbol{\Delta}), \mathrm{NaCl}(\square)$, and $\mathrm{KCl}(\Delta)$. Data are plotted as relative values by taking the activity of intact E3 as $100 \%$. Panel B. After incubation at $4^{\circ} \mathrm{C}$ for $40 \mathrm{~h}, \mathrm{CD}$ spectrum in the far UV region was measured in the presence of $\mathrm{GdnHCl}$. The molecular ellipticity at $222 \mathrm{~nm}$ are plotted by normalization between zero for the value of intact E3 and one for that in $6 \mathrm{M} \mathrm{GdnHCl}$. 
Trp and FAD fluorescence spectra (Fig. 2). The emission maximum of Trp fluorescence spectrum shifted from $335 \mathrm{~nm}$ to $355 \mathrm{~nm}$ (Fig. 2A). In the same conditions, the fluorescence of a NATA molecule was measured as an analogue of Trp residue. The emission maximum of the fluorescence was at $355 \mathrm{~nm}$. Notable changes in the intensity of Trp fluorescence at $340 \mathrm{~nm}$ were detected above $1.2 \mathrm{M} \mathrm{GdnHCl}$; the intensity in $6 \mathrm{M} \mathrm{GdnHCl}$ was 5.5 times that in the absence of $\mathrm{GdnHCl}$ (Fig. 2A). With increasing amount of $\mathrm{GdnHCl}$, the emission maximum of FAD fluorescence spectrum shifted from $542 \mathrm{~nm}$ to $527 \mathrm{~nm}$ (Fig. 2B). The intensity of FAD fluorescence at $520 \mathrm{~nm}$ increased notably; the intensity in $6 \mathrm{M} \mathrm{GdnHCl}$ was 18 times that in the absence of $\mathrm{GdnHCl}$ (Fig. 2B). In similar conditions, fluorescence of free $\mathrm{FAD}$ was measured as a control. Its emission maximum at $528 \mathrm{~nm}$ was unaltered, and the fluorescence intensity in $6 \mathrm{M} \mathrm{GdnHCl}$ was only 1.9 times that in the absence of GdnHCl.

The gel filtration chromatography of $\mathrm{E} 3$ was done in the presence of $\mathrm{GdnHCl}$ (Fig. 3 \& 4). Several peaks were detected in an elution pattern by monitoring $A_{280}$. Intact E3 was eluted at $13.1 \mathrm{ml}$ in the absence of $\mathrm{GdnHCl}$ (Fig. $3 \mathrm{~A}-\mathrm{a}$ ). In $0.2 \mathrm{M} \mathrm{GdnHCl}$, the peak was at $15 \mathrm{ml}$ (Fig. 3A-b). In 1.0 and $1.5 \mathrm{M} \mathrm{GdnHCl}$, the first peak was at $15 \mathrm{ml}$, and the second was at $22 \mathrm{ml}$ (Fig. $3 \mathrm{~A}-\mathrm{c} \& 3 \mathrm{~A}-\mathrm{d}$ ). In $2 \mathrm{M} \mathrm{GdnHCl}$, the first peak was at $12 \mathrm{ml}$, and the second was $22 \mathrm{ml}$ (Fig. $3 \mathrm{~A}-\mathrm{e}$ ). Some of these peak positions were corresponding to elution positions of FAD (Fig. 4A). FAD of intact was at $13.5 \mathrm{ml}$ (Fig. $4 \mathrm{~A}-\mathrm{a}$ ). In $0.2 \mathrm{M}$ $\mathrm{GdnHCl}$, the peak was at $15 \mathrm{ml}$ (Fig. $4 \mathrm{~A}-\mathrm{b}$ ). In 1.0 and $1.5 \mathrm{M} \mathrm{GdnHCl}$, the first peak was at $15 \mathrm{ml}$, and the second was at $22 \mathrm{ml}$ (Fig. $4 \mathrm{~A}-\mathrm{c} \& 4 \mathrm{~A}-\mathrm{d}$ ). In $2 \mathrm{M} \mathrm{GdnHCl}$, the peak was at

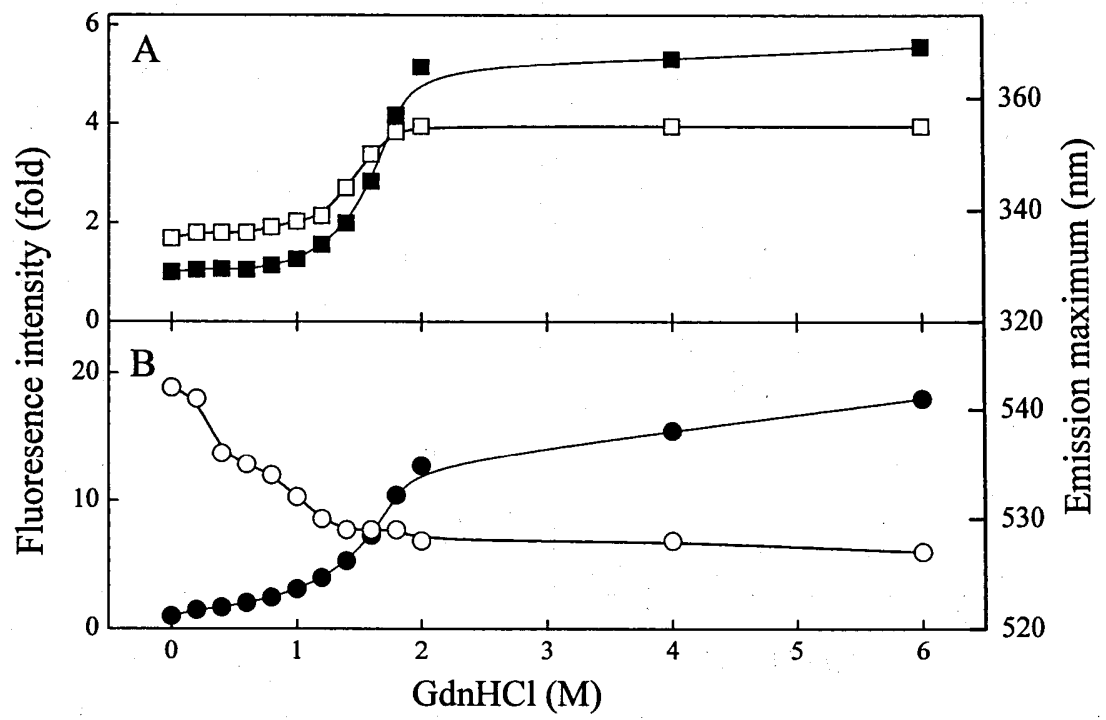

Fig. 2. Changes in intensities of Trp and FAD fluorescence. After incubation at $4^{\circ} \mathrm{C}$ for $24 \mathrm{~h}$, fluorescence spectra ascribed to Trp and FAD were measured in the presence of GdnHCl. Panel A. Emission maximum of Trp fluorescence ( $\square$ ) upon excitation at $295 \mathrm{~nm}$. Panel B. Emission maximum of FAD fluorescence (O) upon excitation at $366 \mathrm{~nm}$. Intensities of Trp and FAD fluorescence at $340 \mathrm{~nm}$ and $520 \mathrm{~nm}$, respectively, are plotted as factors (fold) by taking the corresponding intensity of intact E3 as one. 


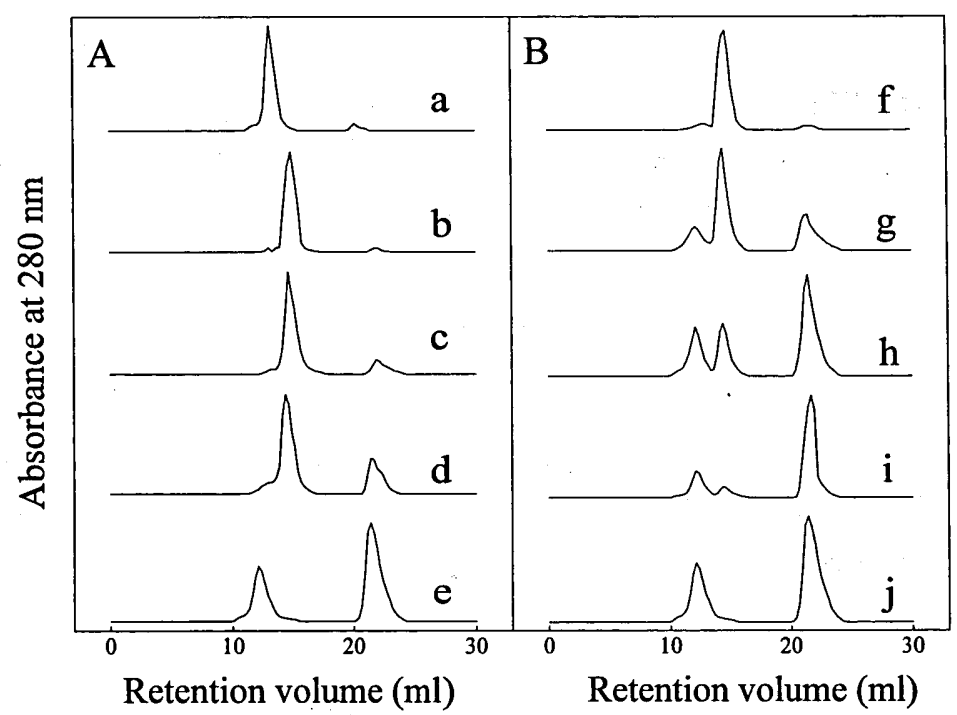

Fig. 3. Changes in gel filtration chromatograms monitored at $280 \mathrm{~nm}$ in the presence of various amounts of $\mathrm{GdnHCl}$ and time-dependent changes in $2 \mathrm{M} \mathrm{GdnHCl}$. In the presence of $0 \mathrm{M}$ (a), $0.2 \mathrm{M}$ (b), $1.0 \mathrm{M}$ (c), $1.5 \mathrm{M}$ (d), and $2.0 \mathrm{M}$ (e) $\mathrm{GdnHCl}, \mathrm{E} 3$ was incubated at $4^{\circ} \mathrm{C}$ for $24 \mathrm{~h}$ and filtered on a Superose $12 \mathrm{HR}$ column. In the presence of $2.0 \mathrm{M} \mathrm{GdnHCl}$, separately, E3 was incubated at $4^{\circ} \mathrm{C}$ for $0 \mathrm{~h} \mathrm{(f),} 1 \mathrm{~h}(\mathrm{~g}), 3 \mathrm{~h}(\mathrm{~h}), 6 \mathrm{~h}(\mathrm{i})$, and $24 \mathrm{~h}(\mathrm{j})$ and filtered on a Superose $12 \mathrm{HR}$ column. Values of absorbance at $280 \mathrm{~nm}$ are plotted in arbitrary units.

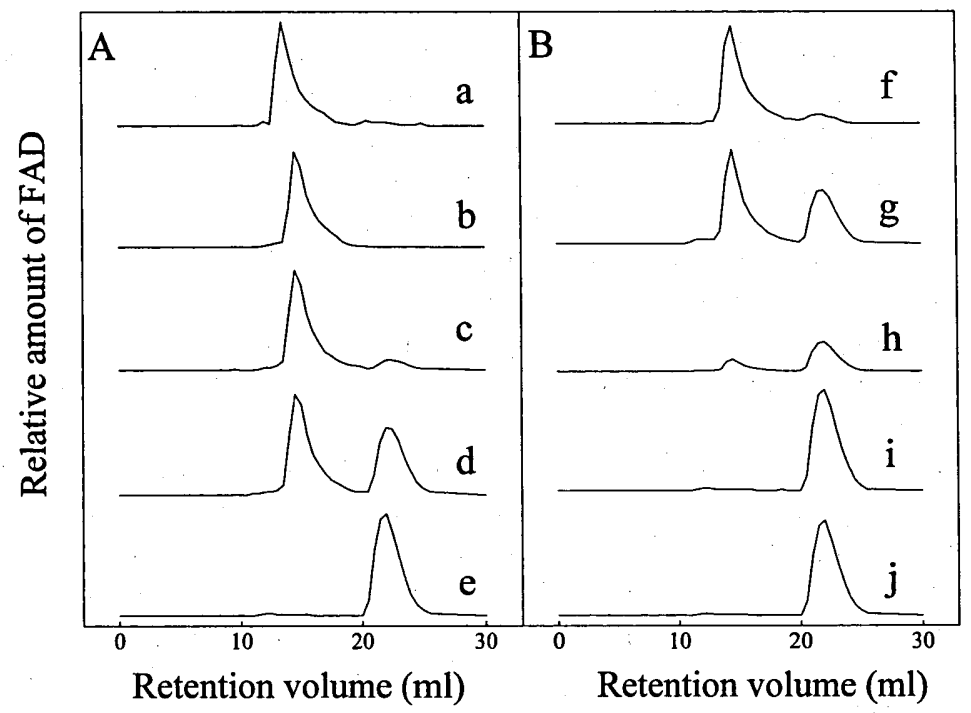

Fig. 4. Changes in elution volume of FAD. Except FAD amount was measured instead of absorbance at $280 \mathrm{~nm}$, experimental conditions are the same as those described in legends for Fig. 3. GdnHCl: $0 \mathrm{M}(\mathrm{a}), 0.2 \mathrm{M}$ (b), 1.0 M (c), 1.5 M (d), and 2.0 M (e). Incubation time: $0 \mathrm{~h}(\mathrm{f}), 1 \mathrm{~h}(\mathrm{~g}), 3 \mathrm{~h}(\mathrm{~h}), 6 \mathrm{~h}(\mathrm{i})$, and $24 \mathrm{~h}(\mathrm{j})$. Data are plotted in arbitrary units. 


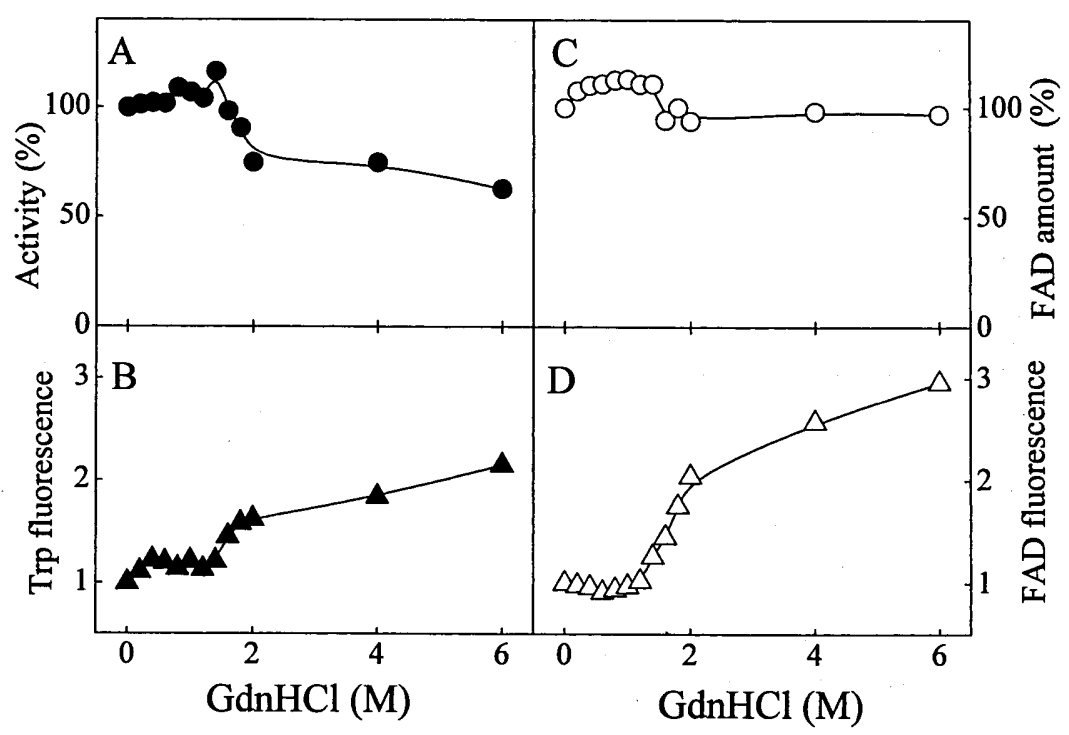

Fig. 5. Changes in enzyme activity and fluorescence intensities by incubation with $\mathrm{GdnHCl}$ and its removal. After incubation at $4^{\circ} \mathrm{C}$ for $24 \mathrm{~h}$, $\mathrm{GdnHCl}$ was successively removed by dialysis at $4^{\circ} \mathrm{C}$ for $48 \mathrm{~h}$. Enzyme activity (A), FAD amount (B), Trp fluorescence (C), and FAD fluorescence (D) were measured. Enzyme activity and FAD amount are plotted by taking the corresponding values of intact E3 as 100\%. Fluorescence intensities are plotted as a factor by taking the corresponding intensity of intact E3 as one.

$22 \mathrm{ml}$ (Fig. 4A-e). Free FAD used as a marker was eluted as a single peak at $22 \mathrm{ml}$. Time-dependent changes were examined by the following method; in the presence of $2 \mathrm{M}$ GdnHCl, E3 was incubated for various times and submitted to the gel filtration (Fig. 3B \& $4 \mathrm{~B})$. With increasing time of incubation, the area of $\mathrm{A}_{280}$ peak detected at $15 \mathrm{ml}$ decreased, while both the area of $\mathrm{A}_{280}$ peaks at $12 \mathrm{ml}$ and $22 \mathrm{ml}$ increased (Fig. 3B). With time, the area of FAD peak at $15 \mathrm{ml}$ decreased, and that at $22 \mathrm{ml}$ increased (Fig. 4B). The molecular size of polypeptide corresponding to the peak at $12 \mathrm{ml}$ was estimated $210 \mathrm{kDa}$. By the sedimentation velocity method using an analytical ultracentrifuge, the molecular sizes of intact E3 in the absence of $\mathrm{GdnHCl}$ and $\mathrm{E} 3$ in $2 \mathrm{M} \mathrm{GdnHCl}$ were estimated 91,600 and 103,500 , respectively.

E3s incubated in the presence of $2 \mathrm{M}$ and $6 \mathrm{M} \mathrm{GdnHCl}$ were dialyzed against standard buffers containing $2 \mathrm{M}$ and $6 \mathrm{M} \mathrm{GdnHCl}$, respectively, and residual amount of FAD in dialyzing tube was measured. After dialysis, $12 \%$ and $5.6 \%$ of $\mathrm{FAD}$ remained in $2 \mathrm{M}$ and $6 \mathrm{M}$ $\mathrm{GdnHCl}$, respectively. As a control, similar experiments were done using free FAD. In both cases, only $0.8 \%$ of FAD remained in the tube. After incubation at $4^{\circ} \mathrm{C}$ for $24 \mathrm{~h}$ and removal of $\mathrm{GdnHCl}$ by dialysis at $4{ }^{\circ} \mathrm{C}$ for $48 \mathrm{~h}$, enzyme activity, $\mathrm{FAD}$ amount, and fluorescence intensities of Trp residue and FAD were measured (Fig. 5). Effects of treatment with $\mathrm{GdnHCl}$ at concentrations less than $1.4 \mathrm{M}$ were almost cancelled. Above the concentration, the effects were partially reduced. On the other hand, FAD amount was mostly recovered: more than $90 \%$ of its original amount. 


\section{DISCUSSION}

Enzyme activity increased notably in the presence of $\mathrm{GdnHCl}, \mathrm{NaCl}$, and $\mathrm{KCl}$, but changed insignificantly in the presence of urea at concentrations less than $1 \mathrm{M}$. Almost no changes in spectrum of Trp fluorescence were detectable, but trivial changes in FAD fluorescence and molecular ellipticity were detected: doubled intensity with a shift of emission maximum by several nanometers, and increasing and decreasing ellipticity. The activity was reduced to the level of original value by the removal of $\mathrm{GdnHCl}$. Based on these results, we considered that changes in ionic strength or presence of chloride ion or both make the micro-environment of E3 more favorable for its catalytic efficiency and that structural changes responsible for increase in activity are never drastic. E3 lost its activity in $1.6 \mathrm{M} \mathrm{GdnHCl}$. This inactivation that was sharply dependent on GdnHCl concentration was accompanied by obvious changes in FAD and Trp fluorescence spectra besides those in far UV CD spectrum. Especially, changes in Trp fluorescence showed a typical two-state transition equilibrium. Since each subunit of E3 has only a Trp residue and an FAD molecule, it was speculated that the increase in both the intensities of fluorescence is reflective of the destruction of an energy transfer between Trp and FAD (Munro and Noble, 1999). The denaturation was suggested to facilitate the dissociation of FAD from E3. Roughly supposing that all the spectroscopic changes are in two-state transition, transition midpoints were evaluated at $1.7 \mathrm{M} \mathrm{GdnHCl}$. Based on results from gel filtration analysis, the release of $\mathrm{FAD}$ was also suggested.

Results from the gel filtration in $2 \mathrm{M} \mathrm{GdnHCl}$ indicated an aggregation into molecular species having $210 \mathrm{kDa}$. Results from analysis by the sedimentation velocity method, however, indicated almost no changes in molecular size: $103.5 \mathrm{kDa}$. In the presence of $\mathrm{GdnHCl}$, polypeptide and FAD were isolated by gel filtration. On the other hand, upon centrifugation, FAD must be uniformly distributed, although $\mathrm{E} 3$ polypeptide sediments to the bottom of centrifugal tube; namely, FAD is never isolated from the polypeptide. Isolation of FAD from E3 polypeptide might trigger an aggregation. FAD was mostly removed by dialysis against buffer containing $\mathrm{GdnHCl}$; not completely. On the other hand, after removal of GdnHCl by dialysis, the recovery of FAD was quite well, although only $60 \%$ of enzyme activity was restored. It was therefore speculated that released $\mathrm{FAD}$ interacts weakly with $\mathrm{E} 3$ polypeptide and that a relatively fast removal of $\mathrm{GdnHCl}$ above $2 \mathrm{M}$ is responsible for wrong re-folding and for wrong configuration of $\mathrm{FAD}$. The thermal denaturation of E3 raises both the Trp and FAD fluorescence intensities (Hiromasa et al., 2000). The thermal denaturation is also accompanied by release of $F A D$, and released FAD is incompletely dialyzed. Inactive aggregate is detected by gel filtration. GdnHCl-induced denaturation of E3 is seemingly similar to thermal denaturation. Recently we reported the GdnHCl-induced changes of PDC; both the incubation and incubation-removal procedures were undergone in the same conditions at $4^{\circ} \mathrm{C}$ (Meno et al., 2002). In the presence of $\mathrm{GdnHCl}$ at concentrations less than $0.3 \mathrm{M}, \mathrm{E} 3$ activity of PDC increases slightly, but decreased above the concentrations. E3 retains only less than $10 \%$ activity in $1.5 \mathrm{M} \mathrm{GdnHCl}$. These results are quite similar to those described in this report, although the incremental activity of isolated E3 was much higher than E3 in PDC. The thermal stability of E3 is improved in PDC, and thermal denaturation is differently dependent on protein concentration (Hiromasa et al., 2000). Recently we observed that the 
formation of E2-E3 complex alters both the thermal denaturation mechanisms of $\mathrm{E} 2$ and E3 (Aso et al., 2002). In other words, GdnHCl-induced denaturation of E3 was similar to that of E3 in a complex, but thermally induced denaturation was not. It was therefore speculated that, upon $\mathrm{GdnHCl}$-induced denaturation, $\mathrm{E} 3$ is dissociated from PDC, namely $\mathrm{E} 2$, and then the denaturation of $\mathrm{E} 3$ proceeds independently of other component enzymes.

\section{REFERENCES}

Allen, M. D. and R. N. Perham 1997 The catalytic domain of dihydrolipoyl acetyltransferase from the pyruvate dehydrogenase multienzyme complex of Bacillus stearothermophilus. Expression, purification and reversible denaturation. EFEBS Lett., 413: 339-343

Aso, Y., Y. Hiromasa, Y. Aikawa, K. Meno and M. Ishiguro 1998 Potassium iodide-induced changes in pyruvate dehydrogenase complex from Bacillus stearothermophilus. Biosci. Biotechnol. Biochem. 62: 108-116

Aso, Y., Y. Satoh, T. Fukuda, T. Hattori, M. Kita, M. Ishiguro, F. Miake and T. Miyata 2002 Thermal inactivation reaction of lipoamide acetyltransferase-dihydrolipoamide dehydrogenase complex. Protein Sci. Suppl. 1, 11: 141

de Kok, A. and W. J. H. van Berkel 1996 Lipoamide dehydrogenase. In "Alpha-Keto Acid Dehydrogenase Complexes", eds. M. S. Patel, T. E. Roche and R. A. Harris, Birkhaeuser Verlag, Berlin, pp. $53-70$

Hiromasa, Y., Y. Aso and S. Yamashita 1993 Purification of the pyruvate dehydrogenase complex from an extreme thermophile, Bacillus caldolyticus. Biosci. Biotechnol. Biochem. 57: 1062-1066

Hiromasa, Y., Y. Aso, S. Yamashita and Y. Aikawa 1995 Homogeneity of the pyruvate dehydrogenase multienzyme complex from Bacillus stearothermophilus. J. Biochem. 117: 467-470

Hiromasa, Y., Y. Aso, S. Yamashita, Y. Aikawa and M. Ishiguro 1997 Further studies on thermal denaturation of pyruvate dehydrogenase complex from Bacillus stearothermophilus. Biosci. Biotechnol. Biochem. 61: 1126-1132

Hiromasa, Y., Y. Aso, S. Yamashita and K. Meno 2000 Thermally induced disintegration of the Bacillus stearothermophilus dihydrolipoamide dehydrogenase. Biosci. Biotechnol. Biochem. 64: 1923-1929

Lebowitz, J., M. S. Lewis and P. Schuck 2002 Modern analytical ultracentrifugation in protein science: a tutorial review. Protein Sci. 11: 2067-2079

Mande, S. S., S. Sarfaty, M. D. Allen, R. N. Perham and W. G. Hol 1996 Protein-protein interactions in the pyruvate dehydrogenase multienzyme complex: dihydrolipoamide dehydrogenase complexed with the binding domain of dihydrolipoamide acetyltransferase. Structure, 4: 277-286

Meno, K., Y. Aso, Y. Hiromasa, T. Irie, M. Kita and M. Ishiguro 2002 Effects of guanidine hydrochloride on pyruvate dehydrogenase complex. J. Fac. Agr., Kyushu Univ., 47: 77-87

Miyata, T., Y. Aso, Y. Satoh, M. Kita, T. Fukuda, T. Hattori, T. Irie, M. Ishiguro and F. Miake 2002 Cloning, sequencing, and overexpression of gene encoding the Bacillus stearothermophilus lipoate acetyltransferase. J. Fac. Agr., Kyushu Univ., 47: 97-107

Munro, A. W. and M. A. Noble 1999 Fluorescence analysis of flavoproteins. In "Flavoprotein Protocols", eds. S. K. Chapman and G. A. Reid, Methods in Molecular Biology, Vol.131, Humana Press, New Jersey, pp. 25-48

Perham, R: N. 1996 Interaction of protein domains in the assembly and mechanism of 2-oxo acid dehydrogenase multienzyme complex. In "Alpha-Keto Acid Dehydrogenase Complexes", eds. M. S. Patel, T. E. Roche and R. A. Harris, Birkhaeuser Verlag, Berlin, pp. 1-15

Perham, R. N. 2000 Swinging arms and swinging domains in multifunctional enzymes: catalytic machines for multistep reactions. Annu. Rev. Biochem., 69: 961-1004

Pace, C. N., B. A. Shirley and J. A. Thomson 1989 Measuring the conformational stability of a protein. In "Protein Structure", ed. T. E. Creighton, IRL Press, Oxford, pp. 311-330

West, S. M., J. E. Rice, E. S. Beaumont, S. M. Kelly, N. C. Price and J. G. Lindsay 1995 Dissociation and unfolding of the pyruvate dehydrogenase complex by guanidinium chloride. Biochem J., $\mathbf{3 0 8}$ : 1025-1029 